\title{
Intramammary pressure and udder firmness during a 72-h interruption of milking to simulate dry-off, with and without feed restriction
}

\author{
Ulrich Blau, Lisa Zanini, and Rupert M. Bruckmaier* \\ Veterinary Physiology, Vetsuisse Faculty, University of Bern, 3012 Bern, Switzerland
}

\begin{abstract}
The goal of the present study was to quantify the increase of intramammary pressure (IMP) in dry-off during an extended milking interval of $72 \mathrm{~h}$. In particular, we tested the hypothesis that feed restriction (no concentrate and roughage with reduced energy) causes earlier cessation of milk secretion and a lower IMP than continued feeding of the lactational diet. In addition to repeated IMP measurements, we tested a noninvasive method that records udder firmness (UF) via external application of pressure on the udder. Two experimental groups consisted of 10 Holstein cows each, with a daily milk yield of 20 to $25 \mathrm{~kg}$. The restricted group (RG) was changed to restricted feeding on the afternoon of the final milking $(0 \mathrm{~h})$, whereas late-lactation feeding was continued in the control group (CG). Both IMP and UF were measured before and after the final milking immediately before milking was stopped for $72 \mathrm{~h}$. These measurements represented IMP and UF levels at $10 \mathrm{~h}$ and $0 \mathrm{~h}$ milking intervals, respectively. Further measurements were performed at 18, 24, 30, 36, 42, 48, and $72 \mathrm{~h}$ after final milking. Milk samples $(2 \mathrm{~mL})$ were taken through the IMP catheter at each sampling event, for analysis of somatic cell count (SCC) and serum albumin (SA). Both IMP and UF increased with time, and both parameters peaked at $30 \mathrm{~h}$ in $\mathrm{CG}$ and at $24 \mathrm{~h}$ in RG. The mean IMP from 18 to $72 \mathrm{~h}$, compared with the 10-h IMP (normal milking interval) was higher in $\mathrm{CG}$ than in RG. The duration of elevated IMP and UF was prolonged in CG compared with RG ( $>36$ h vs. 12 h). The Pearson correlation between IMP and UF was $\mathrm{r}=0.67$. Thus, the noninvasive measurement of $\mathrm{UF}$ is suitable to replace invasive IMP measurements. However, due to individual differences in udder shape, the correlation between UF and IMP was too low to predict exact IMP levels using UF. Both SCC (presented as
\end{abstract}

Received January 19, 2019.

Accepted April 15, 2019.

*Corresponding author: rupert.bruckmaier@vetsuisse.unibe.ch $\log \mathrm{SCC})$ and SA increased after the final milking until the end of the experiment. The mean increase from 18 to $72 \mathrm{~h}$, compared with levels immediately after final milking, was higher in CG than in RG for SCC but did not differ between treatments for SA. In conclusion, feed restriction causes a faster cessation of milk secretion and therefore limits the increase of IMP at dry-off. Key words: intramammary pressure, dry-off, udder firmness, dairy cow

\section{INTRODUCTION}

In nondairy ruminants, milk production peaks shortly after parturition and decreases gradually and slowly thereafter until cessation of lactation. This shape of the lactation curve fulfills the requirements of the offspring that depends on milk only for several weeks after birth. Later on, the calf increasingly feeds on herbage as a prerequisite of ruminal development, and the quantitative contribution of milk as a nutrient source decreases, leading to cessation of lactation (Capuco and Akers, 1999; Bruckmaier and Gross, 2017). In dairy cows, genetic selection has led to substantial increases in milk production, with an average increase of $12 \%$ within only 10 years, from 2008 to 2017 (USDA, 2019). Although this breeding success is most obvious during peak lactation, milk production has also increased considerably in later stages of lactation, affecting the milk yield in late lactation and at dry-off (Ollier et al., 2015). To allow an adequate dry period before the next calving, modern dairy cows are often dried off at a daily milk yield of $20 \mathrm{~kg}$ or even higher. New management strategies such as extended lactation have been successfully tested in research projects (Niozas et al., 2019). However, most working farms still use the traditional system with insemination in early lactation, 305-d lactation, and a dry period of 40 to $60 \mathrm{~d}$ for optimal recovery and preparation of the mammary gland for the next lactation (Arnold and Becker, 1936; Kuhn et al., 2007). In high-yielding dairy cows, the cessation of milk secretion at dry-off must be actively induced. It has been shown that milk synthesis is already downregulated at an ex- 
tended milking interval of $24 \mathrm{~h}$ (Connor, 2008). The regression of the mammary gland is based on apoptosis of lactocytes in late lactation but mainly during the first days after dry-off (Wilde et al., 1997). Involution is actively initiated by apoptotic processes if milk removal is reduced or stopped, resulting in reduced milk synthesis and secretion by lactocytes (Connor, 2008). It has been demonstrated in goats that increase of intramammary pressure (IMP) reduces milk secretion within hours, and the effective IMP increase could also be caused by an intramammary infusion of an isosmotic sucrose solution (Peaker, 1980). To facilitate cessation of milk secretion, farmers use different strategies. Gradual dryoff, such as decreased milking frequency during the last days of lactation, instead of abrupt dry-off, is considered to cause less milk leakage, especially in high-yielding cows. These findings have been interpreted to be due to lower udder pressure during dry-off. Gradual dryoff also improves animal welfare but results in higher workloads for farm personnel (Zobel et al., 2013).

The most effective method of reducing milk production is supposed to be achieved through nutrient and energy deprivation by feed restriction before or at dryoff (Tucker et al., 2009; Bertulat et al., 2015). However, feed restriction is likely to result in a transient negative energy balance, which may affect the capacity of the immune system in the late stage of lactation. Thus, feed restriction during dry-off may increase the risk of IMI (Ingvartsen and Moyes, 2013; Lacasse et al., 2018). In addition to the negative energy balance, there is evidence that increased concentration of plasma free fatty acids due to lipolysis detracts from the function of immune cells (Lacasse et al., 2018). Without consideration of these immunological effects, we investigated the effects of feed restriction on the course of milk secretion and the related IMP during a considerably extended milking interval in the last third of lactation to simulate dry-off during its most crucial period. We tested the hypothesis that IMP would be greater without feed restriction than with it. To characterize a potential loss of blood-milk barrier integrity, we analyzed the patterns of SCC and serum albumin (SA) in milk. In addition, we tested a handheld dynamometer to measure udder firmness (UF; Bertulat et al., 2012) in parallel to IMP measurements, to determine its potential for noninvasive measurement of IMP.

\section{MATERIALS AND METHODS}

Experiments followed the guidelines of the Swiss Law on Animal Protection and Welfare and were approved by the Veterinary Office of the Canton Fribourg (approval no. 201805 FR), Switzerland.
Table 1. Nutrient composition of feed rations

\begin{tabular}{lcccc}
\hline & \multicolumn{2}{c}{ Ration 1} & & Ration 2 \\
\cline { 2 - 3 } \cline { 5 - 5 } Item & $\begin{array}{l}\text { Roughage, } \\
\text { ad libitum }\end{array}$ & $\begin{array}{c}\text { Concentrate, } \\
2 \mathrm{~kg} / \mathrm{d}\end{array}$ & & $\begin{array}{l}\text { Roughage, } \\
\text { ad libitum }\end{array}$ \\
\hline $\mathrm{NE} E_{\mathrm{L}}(\mathrm{MJ} / \mathrm{kg}$ of $\mathrm{DM})$ & 5.4 & 6.7 & & 4.9 \\
$\mathrm{CP}(\mathrm{g} / \mathrm{kg}$ of $\mathrm{DM})$ & 177.0 & 202.0 & & 74.0 \\
\hline
\end{tabular}

\section{Experimental Animals, Housing, Milking, and Feeding}

Twenty non-pregnant Holstein dairy cows were kept in a tie-stall barn for the experimental period at the Swiss Federal Agroscope Research Station, Posieux, Switzerland. Eight cows were in their first lactation, eight in their second, and four in their third or higher. The cows were randomly sorted into a feed-restriction group (RG) or control group (CG). Cows were milked twice daily at 0600 and $1600 \mathrm{~h}$. The mean DIM on the day before interruption of milking was $247 \pm 42$ (SD) in $\mathrm{CG}$ and $214 \pm 84$ in RG, and mean daily milk yield was $24.6 \pm 3.9 \mathrm{~kg} / \mathrm{d}$ in $\mathrm{CG}$ and $21.5 \pm 3.9 \mathrm{~kg} / \mathrm{d}$ in RG. Before interruption of milking, all cows were fed on crop aftermath ad libitum and $2 \mathrm{~kg} / \mathrm{d}$ of concentrate portioned equally during the morning and evening milkings (Table 1).

\section{Measurement of Intramammary Pressure}

Before measuring IMP in one of the rear quarters (randomly selected), the teat orifice was disinfected with gauze soaked in $70 \%$ ethanol. Then a specially constructed sterile steel cannula was inserted through the teat canal into the teat cistern. The whole cannula was $35 \mathrm{~mm}$ long, with an inner diameter of $1.0 \mathrm{~mm}$ and an outer diameter of $1.2 \mathrm{~mm}$. The cannula featured a thickening of $10 \mathrm{~mm}$ length and $2.2 \mathrm{~mm}$ diameter at the end that was inserted into the teat. The rounded thickening of the cannula prevented both injury and slipping out of the teat. Pressure was transmitted through liquid-filled silicone tubing (inner diameter 1 $\mathrm{mm}$ ) to a physiological pressure transducer commonly used for intra-arterial blood pressure recording (SP 844; MEMSCAP AS, Skoppum, Norway). To fill the tubing with sterile $0.9 \%$ saline solution, a 3 -way stopcock was connected to the tubing system. The recorded signal was conveyed to a laptop computer and depicted in specifically adapted software (Kuheuter, V 7.0; IBK Tec, Wiedergeltingen, Germany). Measurements were recorded by the software at 0.05 -s intervals. The tip of the probe was leveled to the teat base and tared to zero to eliminate influences of individual udder size and teat 
length on the recorded pressure. After the insertion of the cannula into the teat, the cannula was flushed with $2 \mathrm{~mL}$ of sterile $\mathrm{NaCl}$ solution $(0.9 \%)$ to ensure that no skin particles blocked the tip of the cannula, as they could influence the measurement. Recordings of IMP lasted for $2 \mathrm{~min}$.

\section{Measurement of Udder Firmness}

Udder firmness of both rear quarters of each cow was measured using a dynamometer (Penefel DFT 14; Agro Technologies, Forges-les-Eaux, France). The device consisted of a 15-mm round brass measuring tip connected to a pressure sensor. As the location to measure, we selected the crossing of the vertical and horizontal centerlines. Centered between the base of the rear teat and the rear quarter attachment, the parenchymal tissue of the mammary gland is located underneath the skin. The tip of the dynamometer was pushed into the quarter perpendicularly to the tissue surface until the plate touched the surface. This ensured a standardized penetration depth of the measuring tip into the udder tissue. The measuring range was 0.05 to $14 \mathrm{~kg}$, with a precision of $\pm 0.04 \mathrm{~kg}$. Five consecutive measurements were taken, and the device calculated means and CV. The procedure we used was validated and described in greater detail by Bertulat et al. (2012). To optimize the repeatability of UF measurements, we marked the measuring point on the skin of the rear quarters.

\section{Milk Sampling and Measurement of Somatic Cell Count and Serum Albumin in Milk}

Milk samples $(2 \mathrm{~mL})$ were taken from the same rear teat used for the IMP measurement through the IMP cannula immediately after each measurement to determine SCC, using a DeLaval Cell Counter (DeLaval, Tumba, Sweden). The remainder of each milk sample was stored at $-80^{\circ} \mathrm{C}$ until measurement of SA. For SA analysis, samples were diluted in ELISA wash buffer (50 m $M$ Tris, $0.14 M \mathrm{NaCl}, 0.05 \%$ polysorbate 20 , adjusted to $\mathrm{pH}$ 8.0). Initial dilution was 1:40,000. The ELISA was performed in duplicate in 96-well plates (Nunc Immuno Plate 439454 MaxiSorp, Thermo Fisher Scientific, Waltham, MA) using SA with a quantitation kit from LubioScience GmbH (Zurich, Switzerland), all according to manufacturers' protocols.

\section{Experimental Protocol}

All experimental cows received ration 1 before dryoff (Table 1). The feeding of RG was changed to the reduced ration 2 (Table 1 ) during the afternoon, when the final milking was performed $(0 \mathrm{~h})$, whereas CG continued to be fed on ration 1 after milking was ceased and until the end of the experiment. Immediately after final milking, all quarters of the experimental cows were treated with $20 \mathrm{~mL}$ of broad-spectrum antibiotics from Dr. E. Graeub AG (Bern, Switzerland), containing $500 \mathrm{mg}$ of gentamicin sulfate and 5 million IU of benzylpenicillinum procaine (Gentapen). Before the first sampling, SCC from all quarters were measured to ensure SCC $<150,000$ cells $/ \mathrm{mL}$. The IMP of one rear quarter was measured immediately before $\left(\mathbf{0}_{\mathrm{b}}\right)$ and after $\left(\mathbf{0}_{\mathrm{a}}\right)$ the final milking before the extended milking interval (representing IMP at 10- and 0-h milking intervals, respectively). Further IMP measurements were performed 18, 24, 30, 36, 42, 48, and $72 \mathrm{~h}$ after final milking. The milk samples for measurement of SCC and SA were taken through the IMP cannula after each IMP measurement, except for the measurement immediately after final milking, $0_{\mathrm{a}}$. To prevent milk loss through leaking, the teats used for IMP measurements were closed with a Genesis Teat Dilator (Henry Schein, Lyssach, Switzerland) until the next measurement. Thereafter, all teats were dipped in an iodine-based disinfecting solution. Last, UF was measured in both rear quarters with a dynamometer at each measuring event.

\section{Statistical Analyses}

The measurements of IMP and UF at $0_{\mathrm{b}}$ were chosen as the reference values for normal udder filling after a 10-h interval from previous milking, to calculate changes during the prolonged milking interval until $72 \mathrm{~h}$. For UF, the average of both rear quarters was used for these calculations. For statistical comparison between treatments, we used the relative delta between 18 and $72 \mathrm{~h}$ after final milking and the $10-\mathrm{h}$ reference value $0_{\mathrm{b}}$.

For statistical testing, we used SAS software (release 9.4; SAS Institute Inc., Cary, NC). The UNIVARIATE procedure was used to test for normal distribution of the data. The data of the IMP were normally distributed, and the data of the UF, SCC, and SA values were logarithmized $\left(\log _{10}\right)$ to achieve normal distribution. The MIXED procedure of SAS was used to test for time and group effects, with the animal as repeated subject. The DIM and milk yield at the start of experiment were used as covariates. Significant differences $(P<0.05)$ at individual time points within and between groups were localized by Tukey's range test. The CORR procedure was used to calculate Pearson correlation between IMP and UF measurements in corresponding quarters (UF of the same quarter where IMP was measured). 


\section{RESULTS}

\section{Intramammary Pressure}

As shown in Figure 1, IMP at $0_{\mathrm{b}}$ was $1.7 \pm 0.3 \mathrm{kPa}$ in $\mathrm{CG}$ and $2.0 \pm 0.3 \mathrm{kPa}$ in $\mathrm{RG}$. The average IMP from 18 to $72 \mathrm{~h}$ was higher than the IMP at $0_{\mathrm{b}}$ in both groups $(P<0.05)$ and was higher $(P<0.05)$ in $\mathrm{CG}(2.3 \pm$ $0.3 \mathrm{kPa})$ than in $\mathrm{RG}(1.3 \pm 0.3 \mathrm{kPa})$. Intramammary pressure at individual time points was elevated from $18 \mathrm{~h}$ until the end of measurements at $72 \mathrm{~h}$ in $\mathrm{CG}(P$ $<0.05$ ), whereas in RG IMP was elevated only from 18 to $36 \mathrm{~h}$ compared with IMP at $0_{\mathrm{b}}(P<0.05$; Figure $1)$. When individual time points were compared, IMP was significantly higher in $\mathrm{CG}$ than in RG $(P<0.05)$ at $30 \mathrm{~h}$ after final milking. Milk yield but not DIM as a covariate had a significant effect on IMP $(P<0.05)$.

\section{Udder Firmness}

As demonstrated in Figure 2, UF at $0_{\mathrm{b}}$ was $1.2 \pm 0.2$ $\mathrm{kg}$ in $\mathrm{CG}$ and $0.8 \pm 0.2 \mathrm{~kg}$ in RG. The average UF from 18 to $72 \mathrm{~h}$ after final milking was significantly higher than UF at $0_{\mathrm{b}}$ in both groups $(P<0.05)$, and average UF was higher $(P<0.05)$ in $\mathrm{CG}(2.0 \pm 0.1 \mathrm{~kg})$ than in $\mathrm{RG}(1.2 \pm 0.1 \mathrm{~kg})$. Udder firmness at individual time points was significantly elevated from 18 to $42 \mathrm{~h}$ in $\mathrm{CG}$, whereas UF in RG was higher only from 18 to

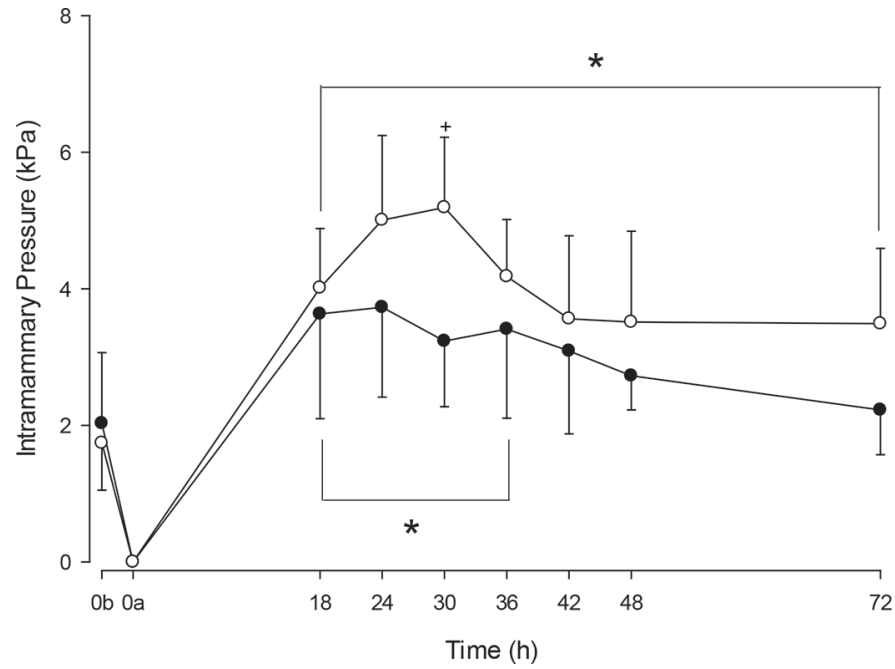

Figure 1. Intramammary pressure (IMP) from 0 to $72 \mathrm{~h}$ after final milking. $\bigcirc=$ control group $(\mathrm{CG}) ; \bullet=$ restriction group $(\mathrm{RG}) ; 0_{\mathrm{b}}$ and $0_{\mathrm{a}}$ are the times immediately before $\left(0_{\mathrm{b}}\right)$ and immediately after $\left(0_{\mathrm{a}}\right)$ the final milking $(10 \mathrm{~h}$ after the last regular milking); $*=$ period of significantly $(P<0.05)$ different IMP compared with IMP at $0_{\mathrm{a}} ;+=$ significant $(P<0.05)$ difference between $\mathrm{CG}$ and $\mathrm{RG}$ at one individual measurement. Error bars represent SEM.
$30 \mathrm{~h}$, compared with UF at $0_{\mathrm{b}}(P<0.05$; Figure 2). When individual time points were compared, UF was significantly higher in CG than in RG $(P<0.05)$ at 30 , 36 , and $42 \mathrm{~h}$ after final milking. Neither milk yield nor DIM as covariates had significant effect on UF.

\section{Correlation Between IMP and UF}

Figure 3 shows the scatter plot and the regression line for all measured values of UF and IMP. The corresponding Pearson's coefficient of correlation between $\mathrm{UF}$ and IMP was $\mathrm{r}=0.67(P<0.05)$.

\section{Somatic Cell Count}

As shown in Figure 4, the logSCC increased gradually with time after final milking for both treatments. This measurement was significantly elevated from 18 to $72 \mathrm{~h}$ in $\mathrm{CG}$, and from 36 to $72 \mathrm{~h}$ in $\mathrm{RG}$, compared with $0_{\mathrm{a}}$ levels. The increase of $\operatorname{logSCC}$ relative to $0 \mathrm{~h}$ was significantly higher in CG $(0.95 \pm 0.10)$ than in RG $(0.44 \pm 0.10 ; P<0.05$; Figure 4$)$. The elevation of $\operatorname{logSCC}$ during the course of the experiment occurred in all 4 quarters and did not differ in quarters used for the various measurements compared with other quarters (data not shown).

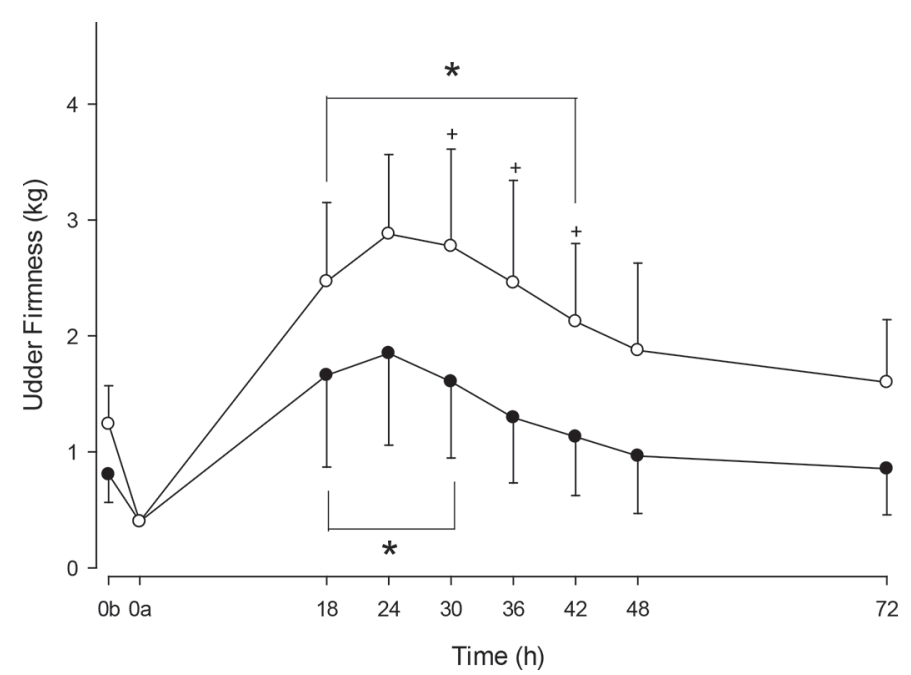

Figure 2. Udder firmness (UF) from 0 to $72 \mathrm{~h}$ after final milking. $\mathrm{O}=$ control group $(\mathrm{CG}) ; \boldsymbol{\bullet}=$ restriction group $(\mathrm{RG}) ; 0_{\mathrm{b}}$ and $0_{\mathrm{a}}$ are the times immediately before $\left(0_{\mathrm{b}}\right)$ and immediately after $\left(0_{\mathrm{a}}\right)$ the final milking $\left(10 \mathrm{~h}\right.$ after the last regular milking); ${ }^{*}=\operatorname{significantly~}(P<$ 0.05) different compared with UF at $0_{\mathrm{a}} ;+=$ significant difference between $\mathrm{CG}$ and $\mathrm{RG}$ at individual time points. Error bars represent SEM. 


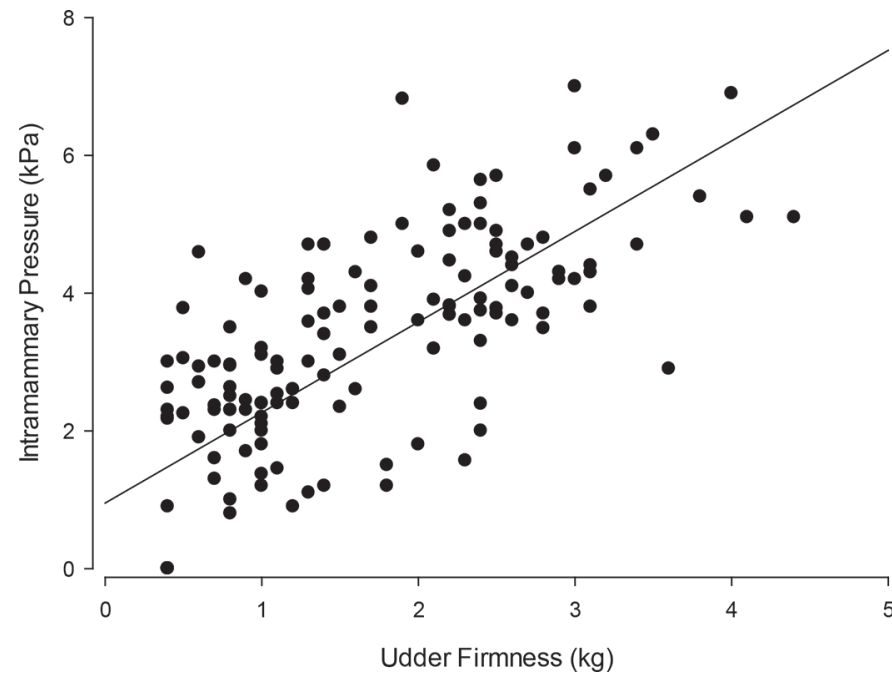

Figure 3. Correlation of intramammary pressure (IMP) and udder firmness (UF), comprising 137 corresponding measurements of IMP and UF of the same rear quarter. Correlation coefficient $=0.67$.

\section{Serum Albumin in Milk}

As shown in Figure 5, SA concentration in milk increased continuously throughout the experiment. Relative to the values at $0_{\mathrm{a}}$, SA was elevated from 24 to 72 $\mathrm{h}$ in $\mathrm{CG}$, and from 18 to $72 \mathrm{~h}$ in $\mathrm{RG}(P<0.05)$. The average elevation of SA from 18 to $72 \mathrm{~h}$, compared with the $0_{\mathrm{a}} \mathrm{SA}$ concentration, was variable and did not differ between CG $(0.33 \pm 0.32 \mathrm{~g} / \mathrm{L})$ and $\mathrm{RG}(0.41 \pm$ $0.32 \mathrm{~g} / \mathrm{L})$.

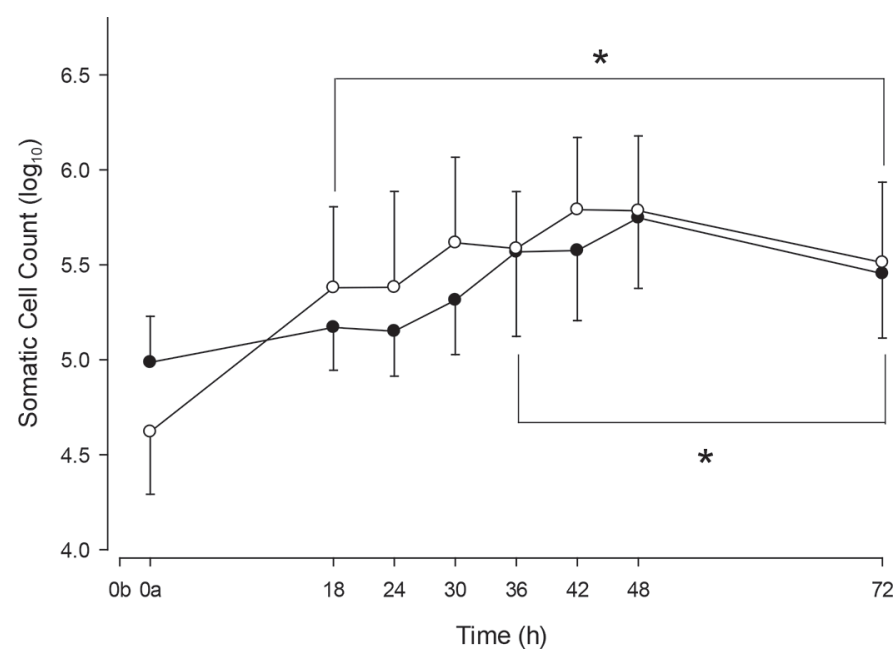

Figure 4. Changes in somatic cell count (SCC) from 0 to $72 \mathrm{~h}$ after dry-off. $\bigcirc=$ control group $(\mathrm{CG}) ; \bullet=$ restriction group $(\mathrm{RG}) ; 0_{\mathrm{b}}$ and $0_{a}$ are the times immediately before $\left(0_{b}\right)$ and immediately after $\left(0_{a}\right)$ the final milking (10 h after the last regular milking); ${ }^{*}=$ significantly $(P<0.05)$ different $\operatorname{logSCC}$ compared with logSCC level at $0_{a}$. Error bars represent SEM.

\section{DISCUSSION}

To our knowledge, the present study is the first investigation of the course of IMP during a considerably extended interval of $72 \mathrm{~h}$ between milkings and simulated dry-off in dairy cows. Most earlier studies have been performed in goats or other nonbovine species (e.g., Peaker, 1980). Metaphylactic treatment with antibiotics was performed because the repeated penetration of the teat canal and the expected milk leakage during the experiment suggest higher risk of IMI, which would impair animal welfare as well as experimental recordings.

The IMP at $0_{\mathrm{b}}$ in our study, which was used as a reference of normal udder filling, was comparable to premilking IMP before milk ejection in earlier studies (Mayer et al., 1991; Bruckmaier and Hilger, 2001). During later stages of lactation, IMP levels in these studies ranged from 1.5 to $2.5 \mathrm{kPa}$. The highest IMP mean values in the present study were $5.1 \mathrm{kPa}$ in CG and $3.7 \mathrm{kPa}$ in RG. Only very few individual IMP levels reached or slightly exceeded the IMP levels measured in earlier work after milk ejection in response to prestimulation prior to milking. In Wellnitz et al. (1999) IMP after milk ejection reached $6.8 \mathrm{kPa}$ at a production rate of $>45 \mathrm{~kg} / \mathrm{d}$, and $5.8 \mathrm{kPa}$ at a production rate of 25 to $30 \mathrm{~kg} / \mathrm{d}$, respectively.

Feeding had an obvious effect on the pattern of IMP. Although the increase in IMP was similar in both groups during the first $18 \mathrm{~h}$ after the start of feed restriction in $\mathrm{RG}$, the IMP increase flattened thereafter, reached

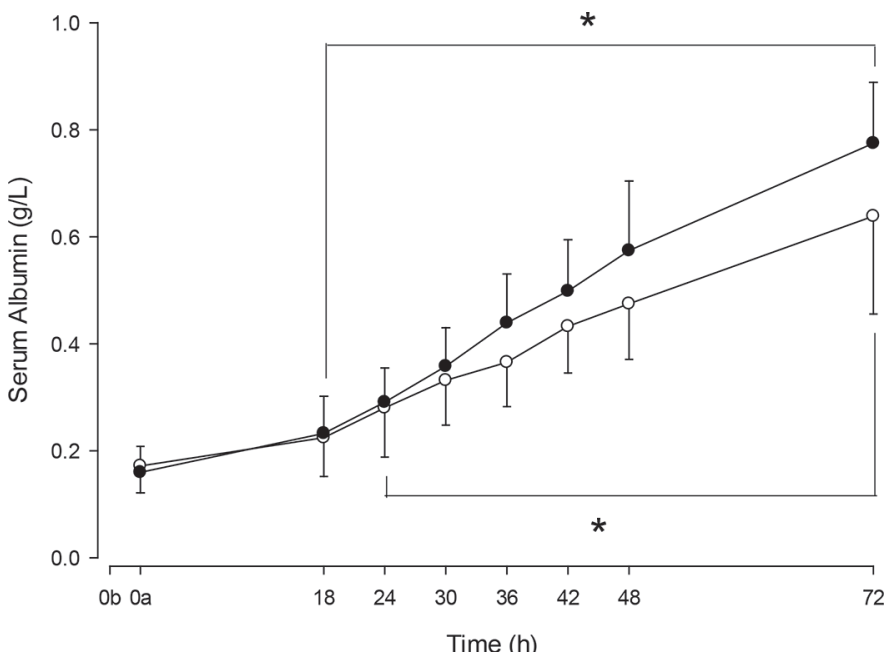

Figure 5. Changes in serum albumin (SA) from 0 to $72 \mathrm{~h}$ after dry-off. $\bigcirc=$ control group $(\mathrm{CG}) ; \bullet=$ restriction group $(\mathrm{RG}) ; \mathrm{O}_{\mathrm{b}}$ and $0_{\mathrm{a}}$ are the times immediately before $\left(0_{\mathrm{b}}\right)$ and immediately after $\left(0_{\mathrm{a}}\right)$ the final milking $\left(10 \mathrm{~h}\right.$ after the last regular milking); ${ }^{*}=$ significantly $(P<0.05)$ different SA compared with SA level at $0_{\mathrm{a}}$. Error bars represent SEM. 
its maximum at $24 \mathrm{~h}$, and decreased slowly but steadily afterward in RG, whereas IMP continued to increase in CG until $30 \mathrm{~h}$. The considerably higher peak IMP in CG was also related to the longer duration of elevated IMP in CG until the end of the experiment. Thus, our study confirms that feed restriction is an efficient tool to limit milk secretion during dry-off.

Unlike IMP, which can be as low as $0 \mathrm{kPa}$ immediately after milking, UF has always a positive value. The UF value of around $0.4 \mathrm{~kg}$ immediately after milking is consistent with earlier research (Bertulat et al., 2015). Because IMP in the absence of oxytocin reflects only the pressure of the milk in the cisternal compartment of the udder (Mayer et al., 1991), UF is obviously also affected by the tension of the udder tissue as well of milk present in the alveolar compartment. The measured UF value can therefore never be zero, and the correlation between IMP and UF is not extremely high. However, depending upon the scientific topic, the noninvasive measurement of UF appears to be a suitable method to describe the time course of increasing and decreasing IMP during dry-off, without the potential infection risk of repeated invasive IMP measurement. In addition, differences in the measured UF values reflect differences in IMP, although the absolute levels of IMP can only roughly be predicted. Data from the present study demonstrate that the duration of pressure increase and decrease can be recorded by UF, although absolute IMP levels cannot be measured via UF. Also, the inhibitory effect of feed restriction on milk secretion could be visualized by both IMP and UF measurements. The advantage of UF measurement is mainly the possibility of measurement of a larger number of animals during different dry-off procedures. The limitations of UF are well illustrated in the present study at $0_{\mathrm{b}}, 10 \mathrm{~h}$ after the last regular milking. Whereas IMP was almost identical in both experimental groups, UF differed considerably between CG and RG.

The increase of SCC and SA in milk during the period of dry-off is well documented in the literature (Lakic et al., 2011; Ollier et al., 2013, 2014). The higher SCC in CG than in RG during the course of the experiment can be interpreted as a more pronounced loss of integrity in the blood-milk barrier because of the delayed decrease of milk secretion. Unlike SCC, the increase of SA in milk did not differ between CG and RG throughout the experiment. This indicates that the different levels of IMP affected the blood-milk barrier differently for different pathways of transfer. Whereas in the transfer of somatic cells (as measured by SCC), active mechanisms such as chemotaxis are involved (Wall et al., 2015), SA is supposed to follow only a passive diffusion via leaky tight junctions. Ponchon et al. (2017) showed congruent increases in SCC and SA after final milking. The plateau of SCC in both groups, and the similar elevation of SCC in all quarters (whether repeatedly sampled or not), confirms that an iatrogenic effect from repeated penetration of the teat canal is unlikely. In the present study, it was not possible to consider a potential difference in risk of IMI between CG and RG. To ensure reliable and repeatable measurements of IMP, we had to exclude IMI in this study and therefore treated the cows with antibiotics.

The mammary gland has a prioritized position in the metabolic regulation of the cow during early stages of lactation, to ensure the milk supply of the offspring (Gross et al., 2011; Opsomer, 2015). Therefore, milk production increases during the first weeks of lactation despite a negative energy balance, and the deficiency is compensated through mobilization of body reserves (Gross et al., 2011). In contrast, during later stages of lactation, the mammary gland gradually becomes homeostatically regulated through insulin. Nutrient and energy deficiency leading to reduced insulin concentrations is compensated by reduction of milk secretion (Gross et al., 2011; Mattmiller et al., 2011). In the present study, all cows in both CG and RG were in the third trimester of lactation. It was obvious in both groups that the abrupt cessation of milking caused a reduction of milk secretion within the experimental period, likely through feedback mechanisms of milk secretion by serotonin or other autocrine regulators, if secreted milk remained in the parenchymal compartment of the mammary gland (Weaver and Hernandez, 2016). As hypothesized, the energy and nutrient deficiency induced by feed restriction had an additional inhibitory effect on milk secretion (Lacy-Hulbert et al., 1999; Gross et al., 2011). Thus, both abrupt cessation of milking and feed restriction had additive inhibitory effects on milk secretion.

It is well known that high IMP may cause milk leakage from the teats (Rovai et al., 2007; Bertulat et al., 2017), which can also be related to increased risk of intramammary infection. Therefore, feed restriction to reduce maximum IMP and to speed up the process of dry-off may be warranted (Gleeson et al., 2007; Gabbi et al., 2016). The potential effects of feed restriction on the function of the immune system must be considered, and possibly feed restriction should be limited, to prevent increased risk of intramammary and other infections (Odensten et al., 2007; Lacasse et al., 2018). Because feed restriction during the dry period is almost indispensable to avoid obesity, with its associated complications, at calving and in early lactation, the diet needs to be changed (Roche et al., 2013). However, it may be debated whether the change in the feed ration 
can be postponed for a few days until the cessation of milk secretion has led to much lower energy and nutrient requirements. However, the controversial effects of feed restriction could not be investigated during the present study. Further investigation, with consideration of animal welfare and reduced use of antimicrobial treatments at dry-off, will be needed.

\section{CONCLUSIONS}

The present study showed that abrupt dry-off at a daily milk production $>20 \mathrm{~kg}$ caused an increase in IMP, with a maximum at about $24 \mathrm{~h}$ and lasting up to $2 \mathrm{~d}$. The maximum IMP at dry-off remained below levels that had been recorded as maximum IMP before milking during early lactation. Starting restricted feeding concomitantly with the cessation of milking leads to considerably lower IMP levels than does dry-off during continued feeding of a lactation diet. Udder firmness measured with a dynamometer followed a similar pattern to that of IMP measurements. Noninvasive measurements of UF have limited ability to predict absolute IMP levels. However, UF is a suitable parameter to determine the time course of increasing and subsequently decreasing IMP, when different methods of dry-off are compared. Because UF, like IMP, increases less in response to feed restriction, lower levels of UF indicate lower IMP, although the absolute value of IMP may not be known.

\section{ACKNOWLEDGMENTS}

The authors thank Kaspar Krogh (Ceva Santé Animale, Libourne, France), for providing the dynamometer device used in this study. We also gratefully acknowledge the support in data management and statistical evaluations of Marina Odorcic and Monica Caldeira (Veterinary Physiology, University of Bern, Switzerland).

\section{REFERENCES}

Arnold, P. T. D., and R. B. Becker. 1936. Influence of preceding dry period and of mineral supplement on lactation. J. Dairy Sci. 19:257-266. https://doi.org/10.3168/jds.S0022-0302(36)93061-8.

Bertulat, S., C. Fischer-Tenhagen, and W. Heuwieser. 2015. A survey of drying-off practices on commercial dairy farms in northern Germany and a comparison to science-based recommendations. Vet. Rec. Open 2:e000068. https://doi.org/10.1136/vetreco-2014 -000068 .

Bertulat, S., C. Fischer-Tenhagen, A. Werner, and W. Heuwieser 2012. Technical note: Validating a dynamometer for noninvasive measuring of udder firmness in dairy cows. J. Dairy Sci. 95:65506556. https://doi.org/10.3168/jds.2012-5370.

Bertulat, S., N. Isaka, A. de Prado, A. Lopez, T. Hetreau, and W. Heuwieser. 2017. Effect of a single injection of cabergoline at dry off on udder characteristics in high-yielding dairy cows. J. Dairy Sci. 100:3220-3232. https://doi.org/10.3168/jds.2015-10220.

Bruckmaier, R. M., and J. J. Gross. 2017. Lactational challenges in transition dairy cows. Anim. Prod. Sci. 57:1471-1481.

Bruckmaier, R. M., and M. Hilger. 2001. Milk ejection in dairy cows at different degrees of udder filling. J. Dairy Res. 68:369-376. https:/ /doi.org/10.1017/S0022029901005015.

Capuco, A. V., and R. M. Akers. 1999. Mammary involution in dairy animals. J. Mammary Gland Biol. Neoplasia 4:137-144. https:// doi.org/10.1023/A:1018769022990.

Connor, E. E. 2008. Effects of reduced frequency of milk removal on gene expression in the bovine mammary gland. BMC Genomics 41:21-32. https://doi.org/10.1152/physiolgenomics.00108.2009.

Gabbi, A. M., C. M. McManus, M. B. Zanela, M. T. Stumpf, R. S Barbosa, V. Fruscalso, A. Thaler Neto, F. A. Schmidt, and V. Fischer. 2016. Milk traits of lactating cows submitted to feed restriction. Trop. Anim. Health Prod. 48:37-43. https://doi.org/10 .1007/s11250-015-0916-2

Gleeson, D. E., B. O'Brien, L. Boyle, and B. Earley. 2007. Effect of milking frequency and nutritional level on aspects of the health and welfare of dairy cows. Animal 1:125-132. https://doi.org/10 $.1017 /$ S1751731107658030.

Gross, J., H. A. van Dorland, R. M. Bruckmaier, and F. J. Schwarz. 2011. Performance and metabolic profile of dairy cows during a lactational and deliberately induced negative energy balance with subsequent realimentation. J. Dairy Sci. 94:1820-1830. https://doi .org $/ 10.3168 /$ jds.2010-3707.

Ingvartsen, K. L., and K. Moyes. 2013. Nutrition, immune function and health of dairy cattle. Animal 7:112-122. https://doi.org/10 $.1017 / \mathrm{S} 175173111200170 \mathrm{X}$

Kuhn, M. T., J. L. Hutchison, and H. D. Norman. 2007. Dry period length in US Jerseys: Characterization and effects on performance. J. Dairy Sci. 90:2069-2081. https://doi.org/10.3168/jds.2006-702.

Lacasse, P., N. Vanacker, S. Ollier, and C. Ster. 2018. Innovative dairy cow management to improve resistance to metabolic and infectious diseases during the transition period. Res. Vet. Sci. 116:40-46. https://doi.org/10.1016/j.rvsc.2017.06.020.

Lacy-Hulbert, S. J., M. W. Woolford, G. D. Nicholas, C. G. Prosser, and K. Stelwagen. 1999. Effect of milking frequency and pasture intake on milk yield and composition of late lactation cows. J. Dairy Sci. 82:1232-1239. https://doi.org/10.3168/jds.S0022 -0302(99)75346-4.

Lakic, B., K. Svennersten Sjaunja, L. Norell, J. Dernfalk, and K. Östensson. 2011. The effect of a single prolonged milking interval on inflammatory parameters, milk composition and yield in dairy cows. Vet. Immunol. Immunopathol. 140:110-118. https://doi.org/ $10.1016 /$ j.vetimm.2010.11.022.

Mattmiller, S. A., C. M. Corl, J. C. Gandy, J. J. Loor, and L. M. Sordillo. 2011. Glucose transporter and hypoxia-associated gene expression in the mammary gland of transition dairy cattle. J. Dairy Sci. 94:2912-2922. https://doi.org/10.3168/jds.2010-3936.

Mayer, H., R. Bruckmaier, and D. Schams. 1991. Lactational changes in oxytocin release, intramammary pressure and milking characteristics in dairy cows. J. Dairy Res. 58:159-169. https://doi.org/ 10.1017/S0022029900029708.

Niozas, G., G. Tsousis, C. Malesios, I. Steinhöfel, C. Boscos, H. Bollwein, and M. Kaske. 2019. Extended lactation in high-yielding dairy cows. II. Effects on milk production, udder health, and body measurements. J. Dairy Sci. 102:811-823. https://doi.org/ $10.3168 /$ jds.2018-15117.

Odensten, M. O., K. Holtenius, and K. P. Waller. 2007. Effects of two different feeding strategies during dry-off on certain health aspects of dairy cows. J. Dairy Sci. 90:898-907. https://doi.org/10.3168/ jds.S0022-0302(07)71573-4.

Ollier, S., X. Zhao, and P. Lacasse. 2013. Effect of prolactin-release inhibition on milk production and mammary gland involution at drying-off in cows. J. Dairy Sci. 96:335-343. https://doi.org/10 $.3168 /$ jds.2012-5955.

Ollier, S., X. Zhao, and P. Lacasse. 2014. Effects of feed restriction and prolactin-release inhibition at drying off on metabolism and mam- 
mary gland involution in cows. J. Dairy Sci. 97:4942-4954. https:/ /doi.org/10.3168/jds.2014-7914.

Ollier, S., X. Zhao, and P. Lacasse. 2015. Effects of feed restriction and prolactin-release inhibition at drying-off on susceptibility to new intramammary infection in cows. J. Dairy Sci. 98:221-228. https:/ /doi.org/10.3168/jds.2014-8426.

Opsomer, G. 2015. Interaction between metabolic challenges and productivity in high yielding dairy cows. Jpn. J. Vet. Res. 63:S1-S14 https://doi.org/10.14943/jjvr.63.suppl.s1.

Peaker, M. 1980. The effect of raised intramammary pressure on mammary function in the goat in relation to the cessation of lactation. J. Physiol. 301:415-428.

Ponchon, B., P. Lacasse, S. Ollier, and X. Zhao. 2017. Effects of photoperiod modulation and melatonin feeding around drying-off on bovine mammary gland involution. J. Dairy Sci. 100:8496-8506. https://doi.org/10.3168/jds.2016-12272.

Roche, J. R., K. A. Macdonald, K. E. Schütz, L. R. Matthews, G. A. Verkerk, S. Meier, J. J. Loor, A. R. Rogers, J. McGowan, S. R. Morgan, S. Taukiri, and J. R. Webster. 2013. Calving body condition score affects indicators of health in grazing dairy cows. J. Dairy Sci. 96:5811-5825. https://doi.org/10.3168/jds.2013-6600.

Rovai, M., M. T. Kollmann, and R. M. Bruckmaier. 2007. Incontinentia lactis: Physiology and anatomy conducive to milk leakage in dairy cows. J. Dairy Sci. 90:682-690. https://doi.org/10.3168/jds S0022-0302(07)71551-5.
Tucker, C. B., S. J. Lacy-Hulbert, and J. R. Webster. 2009. Effect of milking frequency and feeding level before and after dry off on dairy cattle behavior and udder characteristics. J. Dairy Sci. 92:3194-3203. https://doi.org/10.3168/jds.2008-1930.

USDA (United States Department of Agriculture). 2019. Milk: Production per cow by year, 2009-2018, United States. Accessed Dec. 20, 2018. https://www.nass.usda.gov/Charts_and_Maps/Milk _Production_and_Milk_Cows/cowrates.php.

Wall, S. K., J. J. Gross, E. C. Kessler, K. Villez, and R. M. Bruckmaier. 2015. Blood-derived proteins in milk at start of lactation Indicators of active or passive transfer. J. Dairy Sci. 98:7748-7756. https://doi.org/10.3168/jds.2015-9440.

Weaver, S. R., and L. L. Hernandez. 2016. Autocrine-paracrine regulation of the mammary gland. J. Dairy Sci. 99:842-853. https://doi .org/10.3168/jds.2015-9828.

Wellnitz, O., A. Baumert, M. Saudenowa, and R. M. Bruckmaier. 1999. Milk ejection and milk removal of single quarters in high yielding dairy cows. Milchwissenschaft 54:303-306.

Wilde, C. J., L. H. Quarrie, E. Tonner, D. J. Flint, and M. Peaker. 1997. Mammary apoptosis. Livest. Prod. Sci. 50:29-37. https://doi .org/10.1016/S0301-6226(97)00070-5.

Zobel, G., K. Leslie, D. M. Weary, and M. A. G. von Keyserlingk. 2013. Gradual cessation of milking reduces milk leakage and motivation to be milked in dairy cows at dry-off. J. Dairy Sci. 96:5064-5071. https://doi.org/10.3168/jds.2012-6501. 